\title{
Engineering geological and geotechnical assessment of floor of Control Building of Nuclear Reactors- $7 \& 8$ of Rajasthan Atomic Power Project, Rawatbhata, India
}

\author{
Prasnna Jain, AK Naithani, Rabi Bhusan, \\ LG Singh and DS Rawat \\ National Institute of Rock Mechanics \\ Bengaluru, India \\ jainprasnna@gmail.com
}

\author{
A Shrivastava, NM Rao and JK Jain \\ Nuclear Power Corporation of India Ltd. \\ Mumbai, Rajasthan
}

\author{
P.C. Nawani \\ Consultant Engg. Geologist \\ Gurgaon, India
}

\begin{abstract}
To verify whether in-situ conditions have been realistically estimated during investigation and to furnish the permanent data set for the interpretation of geological conditions, foundation floor mapping of important structure like control building of nuclear power plant is essential. At Rawatbhata, adjacent to existing Rajasthan Atomic Power Project (RAPP) units 1 to 6, two units of 700 MWe each Pressurized Heavy Water Reactor (PHWR) type Nuclear Reactors are being constructed. Engineering geological mapping on 1:100 scale was carried out for Control Building of NB-7\&8. Geotechnical assessment of the foundation of control building was done on the basis of detailed engineering geological mapping, geological drill holes logging data, rock mass permeability values, geophysical profiling and laboratory test results. Based on the field observations and evidences, it was found that the entire floor area consists of fine to medium grained, compact greyish white quartzitic sandstone and yellowish brown ferruginous sandstone. The floor region was seen to contain certain iron stained and weathered zone. No evidence of faulting or shearing was observed on the surface of the floor area.
\end{abstract}

Keywords-nuclear reactor; control building; engineering geological; raft foundation; discontinuity; Rawatbhata

\section{INTRODUCTION}

The under construction Rajasthan Atomic Power Project (RAPP) consists of two units 7 and 8 of $700 \mathrm{MWe}$ each Pressurised Heavy Water Reactor (PHWR) type Nuclear Reactors, adjacent to the existing RAPS- 1 to 6 units. In the plant layout, RB 7 and 8 are located at 108 meter center to center. RAPP-7 \& 8 site is located on the right bank of the Chambal River, about $670 \mathrm{~m}$ from Reactor Building 5\&6, in Kherli block under Tehsil of Rawatbhata in Chittorgarh District of Rajasthan. The site is situated about $64 \mathrm{~km}$ from Kota. The approximate latitude and longitude of the site are:
$\mathrm{N} 24^{\circ} 52^{\prime}$ and $\mathrm{E} 75^{\circ} 37^{\prime}$ respectively. The site is on a gently sloping terrain and rocks are available within a few centimeters from the surface.

In order to evaluate the design basis foundation parameters for Control Building (CB) of Nuclear Buildings (NB-7\&8) engineering geological mapping on 1:100 scale was carried out. A separate Control Building, common for both units, has been provided on the construction east of Nuclear Buildings to house Main Control Rooms (MCR) \& Control Equipment Rooms (CER), main steam lines, for both units. In addition, the Control Building acts as a main entrance to the station complex and is located appropriately. The building is a framed structure with a basement/raft at EL $92.00 \mathrm{~m}$ and floors at EL $100.00 \mathrm{~m}$, EL106.00 m, EL $111.00 \mathrm{~m}$, EL 116.00 and roof at EL $124.00 \mathrm{~m}$. All the discontinuities in the rock mass of $\mathrm{CB}$ with the zone of influence of the foundation and walls were identified and mapped. The primary purpose of the mapping was to provide a permanent record of conditions during the excavation. Mapping data was used to assess the requirement of any ground improvement by adopting suitable engineering measures.

\section{METHODOLOGY}

Grids of $1 \mathrm{~m} \times 1 \mathrm{~m}$ were prepared for mapping of the floor, which was decided based on the mapping accuracy and resolution required for such investigations. The vertical and horizontal scale of one grid of construction drawing was $20 \mathrm{~m}$ and as the area was mapped in 1:100 scale, the mapping grids $(1 \mathrm{~m} \mathrm{x} 1 \mathrm{~m})$ were marked within one construction grid e.g. $15,15+1,15+2, \ldots . .15+19,16$ for northing and $z, z^{+1}, z^{+} 2, \ldots \ldots z+19, z 2$ for easting. Basic nomenclature for northing and easting was adopted from the constructing drawing. All the lithological and structural 
features were observed and mapped using Total Station surveying equipment. Detailed examination of rock types in each grid were carried out. Fracture fillings that have taken place in the study site were examined and recorded. The attitude of structural elements in the rocks, fracture and joint patterns present in the floor were determined during mapping. ISRM [1] classification for weathered mass was used to characterize the rock mass into different weathering grades (Table I). The assessment of RMR [2] for sandstone rock masses was done based on the characteristics of bedding planes and jointing pattern, drill cores and laboratory test data.

TABLE I. DESCRIPTION OF WEATHERING GRADE [2]

\begin{tabular}{|l|l|c|}
\hline Term & Description & Grade \\
\hline Fresh & $\begin{array}{l}\text { No visible sign of rock material weathering; perhaps } \\
\text { slight discolouration on major discontinuity surfaces. }\end{array}$ & I \\
\hline $\begin{array}{l}\text { Slightly } \\
\text { weathered }\end{array}$ & $\begin{array}{l}\text { Discolouration indicates weathering of rock material } \\
\text { and discontinuity surfaces. All the rock material may } \\
\text { be discoloured by weathering and may be somewhat } \\
\text { weaker externally than in its fresh condition. }\end{array}$ & II \\
\hline $\begin{array}{l}\text { Moderatel } \\
\text { weathered }\end{array}$ & $\begin{array}{l}\text { Less than half of the rock material is decomposed } \\
\text { and / or disintegrated to a soil. Fresh or discoloured } \\
\text { rock is present either as a continuous framework or } \\
\text { as core stones. }\end{array}$ & III \\
\hline $\begin{array}{l}\text { Highly } \\
\text { weathered }\end{array}$ & $\begin{array}{l}\text { More than half of the rock material is decomposed } \\
\text { and / or disintegrated to a soil. Fresh or discoloured } \\
\text { rock is present either as a discontinuous framework } \\
\text { or as core stones. }\end{array}$ & IV \\
\hline $\begin{array}{l}\text { Completel } \\
\text { y } \\
\text { weathered }\end{array}$ & $\begin{array}{l}\text { All rock material is decomposed and/or disintegrated } \\
\text { to soil. The original mass structure is largely intact. }\end{array}$ & V \\
\hline $\begin{array}{l}\text { Residual } \\
\text { soil }\end{array}$ & $\begin{array}{l}\text { All rock material is converted to soil. The mass } \\
\text { structure and material fabric are destroyed. There is } \\
\text { a large change in volume, but the soil has not been } \\
\text { significantly transported. }\end{array}$ & VI \\
\hline
\end{tabular}

\section{GeOlOGY OF THE PROJeCT AREA}

The project area is occupied by very hard and competent, fine to medium grained sandstone of Kaimur group of the Upper Vindhyan Supergroup of Proterozoic age (940 \pm 40 million years) [3]. Stratigraphically within the $5 \mathrm{~km}$ radius area of RAPP-7 \& 8, a thick sequence of reddish shale overlain by buff to reddish brown sandstone trending in NW-SE direction and dipping at $4^{\circ}$ to $5^{\circ}$ towards SW has been reported [4]. Usually, beds are horizontal to sub-horizontal and general slope of the area is towards west. The prevalence of ripple marks in the strata is indicative of shallow water origin; the red sandstones of the Kaimur indicate semiarid and continental conditions. The Vindhyan supergroup is unmetamorphosed and except in the lower part it does not show much effect of tectonism [5].

In this area fine to medium grained, compact ferruginous sandstone and quartzitic sandstones are exposed after excavation. Drill holes data of Control Building (ABH-85, ABH-86, ABH-87, ABH-88, ABH-90, ABH-91) confirmed that control building area is covered by thin soil cover (up to $0.5 \mathrm{~m}$ ) except in Nallah portion of Control building, where the thickness of overburden upto $2 \mathrm{~m}$ has been recorded. In general CB area from RL $90.850 \mathrm{~m}$ to RL $88.740 \mathrm{~m}$, fine to medium, fresh, thinly to thickly bedded yellowish-brown ferruginous sandstone and grayish-white quartzitic sandstone with layers of glauconite (up to $1.5 \mathrm{~cm}$ ) have been recorded during the field large scale $(1: 100)$ mapping and logging of drill hole $\mathrm{CBH}-19$, which was drilled from RL $90.05 \mathrm{~m}$ (EL 398.35) in control building area.

In the excavated areas of Control Building two major rock types were mapped i.e., grayish-white quartzitic sandstones and yellowish-brown ferruginous sandstones. In grayish-white quartzitic sandstones, quartz content is $98 \%$ including crystalline siliceous matrix, chlorite and calcite contents, $2 \%$ with accessory cryptocrystalline silica, zircon and apatite and all minerals are very fresh. In ferruginous sandstone spotted appearance of zircon / apatite was recorded during mapping. In ferruginous sandstone quartz contents is $88-89 \%$, iron oxide up to $13 \%$, calcite contents $1 \%$ mainly as matrix with accessory zircon and apatite and all minerals are fresh. Glauconite coating/layer (up to 1.5 $\mathrm{cm}$ ) was recorded along the bedding planes of grayish-white quartzitic sandstones.

The Control Building area was characterized by joints and fractures. The most prominent joint sets are the bedding joints dipping at 2-6 degree in WSW direction. The spacing of bedding joints are varying from $1 \mathrm{~cm}$ to $70 \mathrm{~cm}$. Along horizontal sheared open master bedding joints (HSMBJ), rock mass crushed material up to $20 \mathrm{~cm}$ was recorded. On the basis of persistence and nature/condition of vertical joints recorded at exposed foundation levels of various structural buildings during previous and present mapping they are classified as Master vertical Joint (MVJ) showing strike length more than $100 \mathrm{~m}$ with varying thickness of filling and opening. Major vertical Joint $\left(\mathrm{MV}_{\mathrm{J}}\right)$ showing strike length more than $20 \mathrm{~m}$ but less than $100 \mathrm{~m}$ with minor filling and opening and Vertical Joint (VJ) for joints having less than $20 \mathrm{~m}$ strike length, discontinuous and tight. Master vertical Joints ((MVJ) trending in $\mathrm{N} 260^{\circ}$ has been mapped on the foundation surface of $\mathrm{CB}$ and this joint was also mapped in RB-7 and RAB-7 [6]. All vertical joints show maximum effects within $1 \mathrm{~m}$ zone which are characterized by closely spaced fractures and are slightly weathered (WII). No displacement has been seen along these joints. These all joints which are having an affected zone of maximum 1 $\mathrm{m}$ are considered as the relatively weak zones/moderately fractured zone with no shearing effects. Ripple marks were also mapped in grayish-white quartzitic at foundation level. No structure, other than joints, fractures, shears and ripple marks, was recorded in this area. The general description of lithology, mapped at the foundation level of $\mathrm{CB}$ is given in Table II.

\section{ENGINEERING GEOLOGICAL \& GEOTECHNICAL ASSESSMENTS OF FOUNDATIONS}

\section{A. Geological Mapping}

Foundation floor mapping is essential for all important engineering structures to provide permanent data set for geological interpretations. Excavations made during construction provide opportunities for obtaining additional geological and geotechnical data. Geological mapping of floor was done after the excavation of design foundation level and before the placement of concrete or backfill. 
Photographic records of foundation mapping and treatment was also carried out.

Control Building will be resting as per design on a raft of $2.0 \mathrm{~m}$ thick at about $10 \mathrm{~m}$ below the grade level for functional requirement. On the basis of surface geological mapping and drill core log data of $\mathrm{ABH}-85, \mathrm{ABH}-86, \mathrm{ABH}-$ 87, ABH-88, ABH-90, ABH-91 and $\mathrm{CBH}-19$ the maximum portion of $\mathrm{CB}$ site has been excavated up to the foundation level because rock mass was competent and acceptable for foundation, but in some areas excavation has been done beyond the foundation level because of the layering of quartzitic sandstone and blasting. The total excavated area i.e. $6331.080 \mathrm{~m}^{2}$ of $\mathrm{CB}$ foundation was mapped. Based on the field observations and evidences, it was found that entire floor area consists of fine to medium grained, compact grayish-white quartzitic sandstones and yellowish-brown ferruginous sandstone (Fig. 1). No evidences of faulting or shearing were observed on the surface of floor area. However, there were some isolated patches of weathered / altered rock and small fractures in the rock. The exposed foundation surface is coated with glauconite. The structural features observed during the mapping exercise indicated the need for consolidation grouting so that the entire floor are function as single rock mass.

The floor rock mass was classified to fresh rock as per the weathering grade (W-I). In the southern portion of the CB floor, set of master vertical joints trending between $\mathrm{N} 260^{\circ}$ and $\mathrm{N} 290^{\circ}$ direction with a strike length more than $100 \mathrm{~m}$ was mapped. This feature shown the maximum effects within $1 \mathrm{~m}$, which was characterized by closely spaced fractures and slightly weathered (W-II). Joints are intersected by vertical minor (up to $1 \mathrm{~m}$ ) joint sets at an acute angle. Because of the presence of these criss-cross joints the floor area here is disintegrated. Filling of $1-5 \mathrm{~cm}$ was recorded along this feature may be due to brittle nature of rock mass. No displacement has been observed along this feature. Along this feature the rock mass is relatively weak and moderately fractured in the isolated patches on the surface was observed and no shearing effects was observed on the surface. Joint is tight and crushed rock masses are also well cemented. No cavity or soft material was observed along this joint. Iron staining was recorded along this vertical joint. Along these vertical joints consolidation grouting is required to make the foundation monolithic.

Ripple marks, primary structures produced by the water action at the time of deposition of rock, were also mapped at the foundation level of $\mathrm{CB}$ mainly in the northern part. Apart from the above mentioned structural features, scattered presence of small to medium (1-3 m) and shallow fractures \& cracks due to blasting / excavation was observed in the floor area. These cracks are generally tight but opening up to $2 \mathrm{~mm}$ has been mapped in some areas. Loose and detached rock fragments lying along the vertical cuts on the southwestern portion of the floor area has to be removed before the final treatment. The prominent sets of joints recorded in the fine-medium grained compact grayish-white quartzitic sandstones and yellowish-brown ferruginous sandstone at the foundation of CB are given in Table III.
TABLE II. DESCRIPTION OF LithOLOGY MAPPED AT THE FOUNDATION OF CONTROL BUILDING

\begin{tabular}{|c|c|c|c|c|}
\hline $\begin{array}{l}\text { Super } \\
\text { Group }\end{array}$ & Group & Lithology & Mineral Assemblage & $\begin{array}{l}\text { Type } \\
\text { locality }\end{array}$ \\
\hline \multirow[t]{2}{*}{$\overline{0}$} & \multirow[t]{2}{*}{$\begin{array}{l}\text { Kaimur } \\
\text { Group } \\
\text { Proterozoic } \\
\text { age }(940 \pm \\
40 \text { million } \\
\text { years })\end{array}$} & $\begin{array}{l}\text { Grayish- } \\
\text { white } \\
\text { quartzitic } \\
\text { sandstones }\end{array}$ & 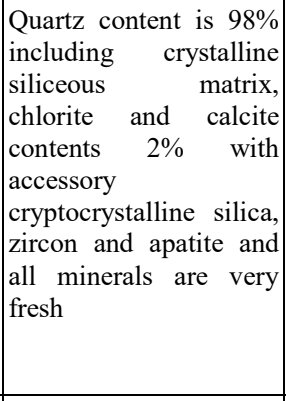 & $\begin{array}{l}\text { South } \\
\text { portion } \\
\text { of CB }\end{array}$ \\
\hline & & $\begin{array}{l}\text { Yellowish- } \\
\text { brown } \\
\text { ferruginous } \\
\text { sandstones }\end{array}$ & $\begin{array}{l}\text { Quartz content is } 86 \% \\
\text { to } 89 \%, \text { chlorite } \\
\text { contents } 1 \% \text {, iron oxide } \\
10 \% \text { to } 13 \% \text { with } \\
\text { accessory zircon and } \\
\text { apatite and all minerals } \\
\text { are very fresh }\end{array}$ & $\begin{array}{l}\text { North } \\
\text { portion } \\
\text { of CB }\end{array}$ \\
\hline $\begin{array}{l}\text { Minera } \\
\text { Mumb }\end{array}$ & $\begin{array}{l}\text { mblage bas } \\
\text { ort [7] }\end{array}$ & on Soham & Foundation Engineering & Pvt. Lt \\
\hline
\end{tabular}

\section{B Laboratory Testing and Geotechnical Assessment}

Selected rock core samples from the boreholes drilled in the control building area were tested for physico-mechanical properties of rocks in the laboratory of Sohams Foundation Engineering Pvt. Ltd [7]. The intact rock properties at the foundation levels given in Table 4 were evaluated considering the necessity in the overall context of the design requirements of the foundations. The values for the dry density of ferruginous/quartzitic sandstones are 2.40 to 2.60 $\mathrm{g} / \mathrm{cc}$ belongs to moderate to high density category. The water absorption values are quite low. Uniaxial compressive strength and deformability characteristic i.e. Modulus of Elasticity and Poisson's ratio were determined.

According to strength classification criterion for rock substance (ISRM, 1981), the rocks are of very high strength. The Modulus of Elasticity values are ranging from 28.00 $\mathrm{GPa}$ to $44.70 \mathrm{GPa}$ and fall under very good rock mass category. Poisson's ratio is 0.30 which is high. Quartzitic sandstone shows higher cohesion. Friction angle is varying from $45^{\circ}$ to $63^{\circ}$ possible due to variation in roughness of the fractured surface. The rock mass properties at the foundation levels, combining geological data, drilling data and geophysical are given in Table 5. Lugeon values are very low indicating that conditions of rock mass discontinuities are very tight. Maximum part of the floor area of the $\mathrm{CB}$ is falling under weathering grade 1 (W-I). The grade of the rock mass as evaluated from the UCS, drill holes cores, core recoveries, RQD and conditions of discontinuities, has RMR values are varying from 65 to 70 and fall under the good rock. 


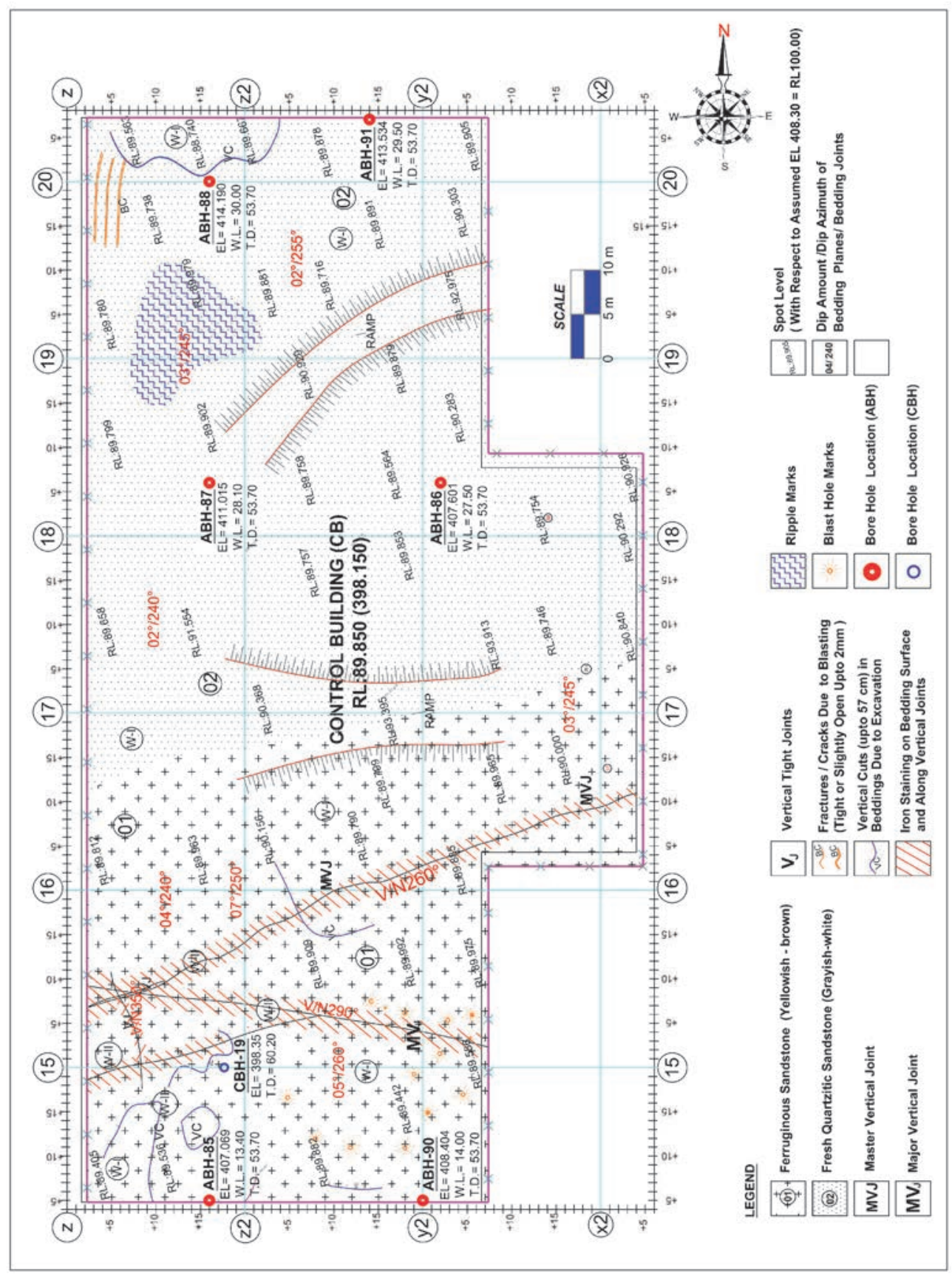

Fig. 1. Geological plan map of Control building of RAPP unit 7\&8

TABLE III. Prominent Joint Sets ReCorded in SANDStones AT the Foundation of CONTROL Building ARea

\begin{tabular}{|l|l|l|l|l|l|l|l|l|}
\hline $\begin{array}{c}\text { Joint } \\
\text { Order }\end{array}$ & $\begin{array}{c}\text { Dip Amount/ } \\
\text { Azimuth/ }\end{array}$ & $\begin{array}{c}\text { Spacing } \\
(\mathbf{c m})\end{array}$ & $\begin{array}{c}\text { Strike length } \\
(\mathbf{m})\end{array}$ & Roughness & $\begin{array}{c}\text { Aperture } \\
(\mathbf{m m})\end{array}$ & Infilling & GW & Remarks \\
\hline I & V/N260 & - & $>100$ & Rough & $2-10$ & Crushed rock fragments and iron oxide coating & Dry & Master Vertical Joint (MVJ) \\
\hline II & V/N290 & - & $>45$ & Rough & $1-5$ & Crushed rock fragments and iron oxide coating & Dry & Major Vertical Joint (MV J) \\
\hline III & V/N350 & - & Up to 15 & Rough & $<2$ & Crushed rock fragments and iron oxide coating & Dry & Vertical Joint (VJ) \\
\hline IV & $2-6 / N 240-260$ & $15-90$ & $>100$ & $\begin{array}{l}\text { Slightly } \\
\text { rough }\end{array}$ & None & Glauconite layer up to 1 cm \& coating & Dry & HTMBJ \\
\hline V & $2-9 / N 240-265$ & $5-15$ & $5-25$ & Slightly & None & None & Dry & Traces of bedding planes \\
\hline V-Ven &
\end{tabular}

V- Vertical joint, HTMBJ- Horizontal tight master bedding joint, GW-Ground water 
TABLE IV. Physico-Mechnical Properties of Intact Rock AT Foundation LeVELs of CONTROL BuILDing

\begin{tabular}{|c|c|c|c|c|c|c|c|c|}
\hline \multirow[b]{2}{*}{ Rock Type } & \multirow{2}{*}{$\begin{array}{l}\text { Dry Density } \\
\text { (g/cc) }\end{array}$} & \multirow{2}{*}{$\begin{array}{c}\text { Water } \\
\text { Absorption } \\
(\%)\end{array}$} & \multirow{2}{*}{$\begin{array}{c}\text { Specific } \\
\text { Gravity }(\mathrm{g} / \mathrm{cc})\end{array}$} & \multirow{2}{*}{$\begin{array}{c}\text { Uniaxial } \\
\text { Compressive } \\
\text { Strength (MPa) }\end{array}$} & \multirow{2}{*}{$\begin{array}{c}\text { Modulus of } \\
\text { Elasticity (GPa) }\end{array}$} & \multirow{2}{*}{$\begin{array}{l}\text { Poisson's } \\
\text { Ratio }\end{array}$} & \multicolumn{2}{|c|}{ Shear Strength Parameter } \\
\hline & & & & & & & Cohesion (MPa) & $\begin{array}{l}\text { Friction Angle } \\
\text { (Degree) }\end{array}$ \\
\hline $\begin{array}{l}\text { Ferruginous } \\
\text { Sandstones }\end{array}$ & $2.40-2.55$ & $0.30-2.00$ & $2.49-2.90$ & $100.20-112.80$ & $28.00-43.00$ & 0.30 & $0.95-3.10$ & $45-62$ \\
\hline $\begin{array}{l}\text { Quartzitic } \\
\text { Sandstones }\end{array}$ & $2.45-2.60$ & $0.24-2.15$ & $2.59-2.98$ & $103.20-116.60$ & $28.02-43.70$ & 0.30 & $0.95-3.10$ & $45-63$ \\
\hline
\end{tabular}

TABLE V. Properties OF Rock MASS AT THE FOUNDATION LEVELS OF CONTROL BuILDING

\begin{tabular}{|c|c|c|c|c|c|c|c|c|c|c|}
\hline \multirow{2}{*}{ Rock Type } & \multirow{2}{*}{$\begin{array}{l}\text { Major } \\
\text { Joints }\end{array}$} & \multirow{2}{*}{$\begin{array}{l}\text { Weatherin } \\
\text { g Grade }\end{array}$} & \multirow{2}{*}{$\begin{array}{l}\text { Core } \\
\text { Recovery } \\
(\%)\end{array}$} & \multirow{2}{*}{$\begin{array}{l}\text { RQD } \\
(\%)\end{array}$} & \multirow{2}{*}{$V p(k m / s e c)$} & \multirow{2}{*}{$\begin{array}{l}\text { Water Level } \\
\text { (m) }\end{array}$} & \multirow{2}{*}{$\begin{array}{l}\text { Permeability } \\
\text { (lugeon) }\end{array}$} & \multicolumn{2}{|l|}{ RMR } & \multirow{2}{*}{$\begin{array}{l}\text { Level of Acceptable } \\
\text { Foundation }(\mathrm{m})\end{array}$} \\
\hline & & & & & & & & $\begin{array}{l}\text { Values } \\
\text { (Range) }\end{array}$ & Class & \\
\hline $\begin{array}{l}\text { Ferruginous } \\
\text { Sandstones }\end{array}$ & $\begin{array}{l}\text { HTMB } \\
\text { J, MVJ, }\end{array}$ & W-I to W-II & 100 & $75-95$ & $3.50-4.20$ & $9.10-12.5$ & $0.06-0.09$ & $65-70$ & $\begin{array}{l}\text { Good } \\
\text { Rock }\end{array}$ & $\begin{array}{l}\mathrm{El}+398.150 \mathrm{~m}(\mathrm{RL} 89.850) \\
\text { for control building }\end{array}$ \\
\hline $\begin{array}{l}\text { Quartzitic } \\
\text { Sandstones }\end{array}$ & $\begin{array}{l}\text { HTMB } \\
\text { J, MVJ, }\end{array}$ & W-I to W-II & 100 & $75-100$ & $3.85-4.40$ & $9.10-12.5$ & $0.05-0.09$ & $65-70$ & $\begin{array}{l}\text { Good } \\
\text { Rock }\end{array}$ & $\begin{array}{l}\mathrm{El}+398.150 \mathrm{~m}(\mathrm{RL} 89.850) \\
\text { for control building }\end{array}$ \\
\hline
\end{tabular}

\section{OBSERVATIONS AND CONCLUSIONS}

Based on the field observations and evidences, it was established that area in the floor of CB site is characterized by grayish-white quartzitic sandstones (containing quartz including crystalline siliceous matrix, chlorite and calcite) and yellowish-brown ferruginous sandstone (containing quartz and calcite as matrix with accessory zircon and apatite). Depth persistence and lateral prevalence of bed rock was established. The floor region is unweathered but prominent vertical joints are present. The floor is falling in W-I weathering grade, and drilling data confirming the same beyond the foundation. The test results and field observations indicate that the rock mass was quite competent and acceptable for the foundation of the CB. It was recommended that only fractured and loose rock material from all along the Vertical Joints should be removed by mechanical breaker and back filled with concrete (>M20, grade having either normal density or heavy density) up to the foundation level to make the foundation monolithic. The structural features observed during the mapping exercise indicated that consolidation grouting up to $9-10 \mathrm{~m}$ should be done in the foundation of CB using primary, secondary and tertiary holes so that the entire floor area function as single rock mass. Regarding the final depth, spacing and pattern of grout holes, trials for the establishment of depth and spacing was recommended at the initial stages of the work. Vertical holes for the grouting were recommended because beds are horizontal to subhorizontal lying. It was recommended to complete blasting before taking up grouting operation. If blasting after grouting is unavoidable, through testing and regrouting is essential after blasting. As in the foundation, compact, massive and hard sandstones were lying, so chance of upheaving was negligible.

\section{ACKNOWLEDGEMENTS}

The authors would like to thank Nuclear Power Corporation of India Limited for permission to send this paper for publication. The present work is a part of a project sponsored by Hindustan Construction Company (HCC), and the authors thank the Management of HCC for the same. We sincerely thank Dr. V. Venkateswarlu, Director, NIRM for providing technical guidance and valuable advice during the preparation of this manuscript.

\section{REFERENCES}

[1] ISRM "International Society for Rock Mechanics (ISRM) suggested methods for rock characterization, testing and monitoring," Editor: E.T. Brown, Published by Pergamon press, p 211, 1981.

[2] Z.T. Bieniawski, 'Engineering rock mass classification” John Willey \& Sons, New York, p. 251, 1989.

[3] B. Prasad "Geology, sedimentation and palaeogeography of the Vindhyan Super Group, South-Eastern Rajasthan,” Mem. GSI, v. 116, Part-I, p. 103, 1984.

[4] S. Prasad, A. Som, A.G. Chhatre, U.P. Singh, and F. Dastageer, (2010) Lineament study and their field check within $5 \mathrm{~km}$ radius of RAPP-7 \& 8, Rawatbhata, Chittorgarh, Rajasthan. NPCIL Report No. NPCIL/SA\&S/01/01400/M, p. 12, 2010.

[5] Y.R. Sathya Saradhi, and D.C. Banerjee, "A note on geology and tectonics around $40 \mathrm{~km}$ of Ranapratapsagar site, Rajasthan," Report of Department of Atomic Energy, Atomic Minerals Division, Hyderabad, p. 5, 1989.

[6] A.K. Naithani, P. Jain,, R. Bhusan, J.K. Jain, and P.C. Nawani, (2016) "Foundation floor engineering geological mapping of nuclear reactor7 of Rajasthan atomic power project, Rawatbhata, India," Special Publication of the Geological Society of India No.4 (in press)

[7] Sohams Foundation Engineering Pvt. Ltd., Mumbai, "Design basis report on geotechnical investigations and evaluation of foundation parameters RAPP-7 \& 8.” p. 334, 2010 